\title{
Herd factors associated with the seroprevalences of four major respiratory pathogens in slaughter pigs from farrow-to-finish pig herds
}

\author{
Dominiek MAES $^{\text {a* }}$, Hubert DeluYKer ${ }^{\mathrm{a}}$, Marc VerdonCK ${ }^{\mathrm{a}}$, \\ Frans CASTRYCK ${ }^{\mathrm{b}}$, Cora Miry ${ }^{\mathrm{b}}$, Bernard VRIJENS ${ }^{\mathrm{c}}$, Aart DE KRUIF ${ }^{\mathrm{a}}$ \\ ${ }^{\text {a }}$ Department of Reproduction, Obstetrics and Herd Health, Faculty of Veterinary Medicine, \\ University of Ghent, Salisburylaan 133, 9820 Merelbeke, Belgium \\ ${ }^{\mathrm{b}}$ Regional Veterinary Investigation Centre, Industrielaan 15, 8820 Torhout, Belgium \\ ${ }^{\mathrm{c}}$ Department of Applied Mathematics and Computer Science, Faculty of Sciences, \\ Krijgslaan 281, 9000 Ghent, Belgium
}

(Received 28 September 1999; accepted 13 January 2000)

\begin{abstract}
The objective of this study was to investigate sero-epidemiological aspects of Mycoplasma hyopneumoniae (Mh), influenza $\mathrm{H}_{1} \mathrm{~N}_{1}$ and $\mathrm{H}_{3} \mathrm{~N}_{2}$ viruses and Aujeszky disease virus (ADV) in fattening pigs from 150 randomly selected farrow-to-finish pig herds. Different herd factors were examined as potential risk indicators for the percentage of pigs with antibodies against the 4 pathogens. The median within-herd seroprevalences of the pathogens were: $\mathrm{Mh} 76 \%, \mathrm{H}_{1} \mathrm{~N}_{1} 100 \%, \mathrm{H}_{3} \mathrm{~N}_{2} 40 \%$ and ADV 53\%. There was a positive association between the seroprevalences of both influenza viruses, and a negative association between the seroprevalences of ADV and $\mathrm{H}_{1} \mathrm{~N}_{1}$. The percentage of pigs seropositive for Mh increased with the purchase of gilts and with the season (slaughter date in MarchApril). The within-herd seroprevalences of both influenza viruses were higher in the case of a higher density of pig herds in the municipality. A higher number of fattening pigs per pen additionally increased the risk of being seropositive for $\mathrm{H}_{3} \mathrm{~N}_{2}$. The percentage of pigs with anti-gE-antibodies against the wild type ADV increased with higher airspace stocking density in the finishing unit, increasing herd size, increasing number of pig herds in the municipality and slaughter date in March-April. Increased seroprevalences for these 4 respiratory pathogens were mostly associated with pig density in the herd and its vicinity, the winter period, and with the purchase of gilts. Purchase of gilts, number of fattening pigs per pen and airspace stocking density are risk factors that can be managed directly by farmers striving to attain a high respiratory health status of pigs.
\end{abstract}

pig / respiratory infections / seroprevalence / epidemiology

* Correspondence and reprints

Tel.: (32) (0)9 26475 41; fax: (32) (0)9 26477 98; e-mail: Dominiek.Maes@ rug.ac.be 
Résumé - Facteurs de risque associés à la séroprévalence des $\mathbf{4}$ principaux agents pathogènes respiratoires chez le porc charcutier provenant d'élevages naisseurs-engraisseurs. L'objectif de ce travail est d'étudier les aspects séro-épidémiologiques vis-à-vis de Mycoplasma hyopneumoniae (Mh), des virus $\mathrm{H}_{1} \mathrm{~N}_{1}$ et $\mathrm{H}_{3} \mathrm{~N}_{2}$ de la grippe porcine et du virus de la maladie d'Aujeszky (VMA) chez des porcs charcutiers provenant de 150 élevages naisseurs-engraisseurs. Les caractéristiques d'élevages ont été étudiées comme étant des indicateurs de risque potentiel de séroprévalence des 4 agents pathogènes. Les séroprévalences médianes à l'échelle des élevages étaient: $\mathrm{Mh} 76 \%, \mathrm{H}_{1} \mathrm{~N}_{1} 100 \%, \mathrm{H}_{3} \mathrm{~N}_{2}$ 40\% et VMA 53\%. Une relation positive était observée entre les séroprévalences des deux virus grippaux. En revanche, une relation négative était mise en évidence entre la séroprévalence de la grippe (virus $\mathrm{H}_{1} \mathrm{~N}_{1}$ ) et celle du VMA. Le pourcentage de porcs séropositifs vis-à-vis de Mh était plus élevé dans les porcheries où les éleveurs avaient introduit de nouvelles cochettes pour la reproduction et lorsque les porcs étaient abattus en mars-avril. La séroprévalence des deux virus grippaux était plus élevée dans les localités à forte densité d'élevages porcins et le risque de séroconversion vis-à-vis du virus $\mathrm{H}_{3} \mathrm{~N}_{2}$ de la grippe porcine augmentait avec le nombre de porcs dans les unités d'engraissement. Le risque de trouver des animaux porteurs d'anticorps anti-gE dirigés contre les souches sauvages du VMA augmentait aussi avec le nombre de porcs présents dans les unités d'engraissement, la taille des élevages, le nombre de porcs dans la localité et les abattages en mars-avril. La séroprévalence vis-à-vis de ces 4 agents pathogènes respiratoires était le plus souvent associée avec la densité de porcs dans les élevages et dans le voisinage, la saison hivernale et après l'acquisition de cochettes pour la reproduction. L'introduction de nouvelles cochettes dans les porcheries, le nombre de porcs par case dans les unités d'engraissement et la densité de population sont des facteurs de risque qui peuvent être contrôlés directement par les exploitants qui veulent atteindre un niveau sanitaire élevé vis-à-vis des maladies respiratoires du porc.

porc / infections respiratoires / séroprévalence / épidémiologie

\section{INTRODUCTION}

With the intensification in pig production, veterinary services that are provided have moved from the so-called first-aid practice into planned prevention and control programs. A successful application of these programs largely depends upon a thorough understanding of the epidemiology of diseases. This is especially true for the prevention of respiratory disorders because they may be multifactorial $[21,34]$.

The present study was conducted to get insight into sero-epidemiological aspects of four important respiratory pathogens in pigs, namely Mycoplasma hyopneumoniae (Mh), influenza $\mathrm{H}_{1} \mathrm{~N}_{1}$ and $\mathrm{H}_{3} \mathrm{~N}_{2}$ viruses and Aujeszky disease virus (ADV). Previous studies focusing on the epidemiology of Mh have been conducted to estimate the seroprevalence of Mh in pig herds [19], and to discern risk factors associated with reinfection of SPF herds with Mh [16, 22, 38, 42]. No information is available, however, about risk factors influencing the proportion of
Mh seropositive pigs per herd. Epidemiological characteristics of porcine influenza viruses have been investigated mainly from a descriptive point of view [17], or else, the emphasis was put on public health aspects [47]. Few studies [11, 12, 13] have so far investigated factors involved in the spread of influenza viruses within and between pig herds. The spread of ADV within and between pig herds has been the subject of many studies in Europe [11, 12, 15, 23, 39] and North-America [2, 4, 31, 46]. However, the results of these studies are not always consistent.

Because pig herds are commonly infected with different respiratory pathogens, it is imperative to investigate the epidemiology of these infections simultaneously in the same study population. Such an approach also allows to compare the epidemiological characteristics of different pathogens, and it guarantees that possible differences between the pathogens are not related to differences in study design. Many of the aforementioned studies have been carried out by 
evaluating unconditional associations between risk factors and disease, or have considered only a limited number of risk factors. In this respect, a multivariate study constitutes a very useful tool to examine a wide range of factors, and to investigate the effects of an individual factor while other factors are held constant.

The present cross-sectional study was conducted to investigate sero-epidemiological characteristics of the aforementioned pathogens simultaneously in 150 randomly selected Belgian farrow-to-finish (FTF) pig herds. The specific aims of the study were (1) to identify risk indicators for the proportion of pigs seropositive for these four respiratory pathogens at slaughter, and (2) to determine the interrelationships of these seroprevalences.

\section{MATERIALS AND METHODS}

\subsection{General features of the study population}

The herds were located in the north-western part of Belgium. This is an area with a surface of $11 \%$ of the country, and which contains $54 \%$ of the Belgian pig population that is, approximately 2.7 million pigs. The study included FTF herds only. In all study herds, ADV vaccination was practised according to the mandatory vaccination scheme that is sows and boars were vacci- nated two times per year with an inactivated vaccine or three times per year with an attenuated vaccine; gilts at least three times before first mating or insemination; fattening pigs (FP) at least once at the start of the fattening period. Vaccination against porcine influenza was practised in $23 \%$ of the herds. None of the herds had practised vaccination against $\mathrm{Mh}$ at least one year before the study was initiated.

\subsection{Selection of herds}

One hundred and fifty FTF pig herds were selected at random from the national registry [36]. A random selection was used to obtain representative data from the population herds. Herds in the area were stratified by herd size into three categories: 50 to 100 sows, 101 to 200 sows, and more than 200 sows. Small herds $(<50$ sows $)$ were excluded because they are unlikely to survive economically in the future. The number of selected herds per herd-size category was proportional to the number of sows in each herd-size category (Tab. I). This selection procedure avoided overrepresentation of the numerous herds with 50 to 100 sows.

First, a letter was mailed to the selected farmers introducing the study and its purpose. Next, they were contacted by phone and asked to collaborate. Thirteen percent $(n=22)$ of the selected herd owners did not

Table I. The number of sows and the number of pig herds per herd-size category in the geographic area and in the study.

\begin{tabular}{|c|c|c|c|c|}
\hline & \multicolumn{3}{|c|}{ Herd-size category } & \multirow[t]{2}{*}{ Total } \\
\hline & $\begin{array}{l}50-100 \\
\text { sows }\end{array}$ & $\begin{array}{l}101-200 \\
\text { sows }\end{array}$ & $\begin{array}{l}>200 \\
\text { sows }\end{array}$ & \\
\hline Number of pig herds in the geographic area & 1132 & 799 & 198 & 2129 \\
\hline Number of sows in the geographic area & 88296 & 115056 & 62766 & 266118 \\
\hline Number of pig herds in the study & 50 & 65 & 35 & 150 \\
\hline $\begin{array}{l}\text { Percentage of pig herds in the geographic area } \\
\text { in the study }\end{array}$ & 4.4 & 8.1 & 17.7 & 7.0 \\
\hline
\end{tabular}


participate for the following reasons: slaughter of FP abroad $(n=5)$, distribution of slaughter pigs to several slaughterhouses $(n=6)$, end of activity $(n=2)$, no FTF herd $(n=2)$, herd size too small $(n=2)$, or refusal to participate $(n=5)$. Random sampling was repeated in corresponding strata to replace these 22 herds.

\subsection{Collection of herd data}

The data were obtained by the first author through inspections of the pigs and the pig units, and through face-to-face interviews of the pig farmers. A questionnaire with precise definitions of the data to be recorded and pertaining to potential risk indicators for respiratory disease was used (Tabs. II and III). The on-farm data were considered to be of sufficient quality because standardised definitions were used for the topics in the questionnaire, and because the data were obtained by one person. Information pertained to herd size, month of slaughter, pig and pig herd density in the municipality, management practices, housing conditions, disease prevention procedures and hygienic measures. All these data were contemporary for the pigs that were examined at slaughter.

Herd size was defined based on the number of sows on the premises. The 12 months during which the study was conducted were grouped in bi-monthly periods using slaughter date. Almost all pure-bred sows were Landrace sows; the remaining were Yorkshire and Large White sows. Crossbreeds, that is at least two-way crosses, were commercial hybrid sows or sows derived from own on-farm selection. In most cases, purchased gilts were bought at the age of 7 months. Herds purchasing gilts from more than one herd comprised herds that bought breeding pigs from multiple sources or from one source per purchase but that used more than one source. A compartment was defined as a subdivision of a building with its own ventilation system. All-in/all-out (AIAO) was considered to take place if the compartment (or the unit) was filled up the same day, was sold in one

Table II. Potential risk indicators for respiratory disease on farrow-to-finish pig herds. Descriptive data of continuous variables.

\begin{tabular}{|c|c|c|c|c|c|c|}
\hline Potential risk indicator & $\mathrm{N}^{\mathrm{a}}$ & Min. & $1^{\circ}$ Quartile & Median & $3^{\circ}$ Quartile & Max. \\
\hline Herd size & 150 & 50 & 100 & 138 & 201 & 600 \\
\hline $\begin{array}{l}\text { Pig density in the municipalities }(\mathrm{n}=56) \\
\text { number of pigs per } \mathrm{km}^{2}\end{array}$ & 150 & 72 & 699 & 953 & 2073 & 3582 \\
\hline number of pig herds per $\mathrm{km}^{2}$ & 150 & 0.5 & 1.8 & 2.3 & 3.3 & 4.7 \\
\hline PASD $^{b}$ in the finishing unit ( $\mathrm{m}^{2}$ per pig) & 150 & 0.43 & 0.66 & 0.69 & 0.75 & 1.50 \\
\hline $\mathrm{ASSD}^{\mathrm{c}}$ in the finishing unit $\left(\mathrm{m}^{3}\right.$ per pig) & 150 & 1.20 & 2.20 & 2.50 & 2.86 & 5.00 \\
\hline $\begin{array}{l}\text { Number of pigs per compartment } \\
\text { in the finishing unit }\end{array}$ & 147 & 75 & 120 & 280 & 400 & 1000 \\
\hline $\begin{array}{l}\text { Number of pigs per pen in the } \\
\text { finishing unit }\end{array}$ & 147 & 5.0 & 12.0 & 13.0 & 15.0 & 23.0 \\
\hline $\begin{array}{l}\text { Number of compartments in the } \\
\text { finishing unit }\end{array}$ & 150 & 1.00 & 1.00 & 1.00 & 4.00 & 16.00 \\
\hline
\end{tabular}

${ }^{a}$ Number of herds for which data were available.

b PASD: pen area stocking density.

${ }^{c}$ ASSD: airspace stocking density. 
Table III. Potential risk indicators for respiratory disease on farrow-to-finish pig herds. Descriptive data of categorical variables.

\begin{tabular}{lcl}
\hline Potential risk indicators & $\mathrm{N}^{\mathrm{a}}$ & Categories (\% of herds in each class) \\
\hline $\begin{array}{l}\text { GENERAL FACTORS } \\
\text { Month of slaughter }\end{array}$ & 150 & $\begin{array}{l}\text { January-February (19), March-April (16), May-June (11), } \\
\text { July-August (14), September-October (21), } \\
\text { November-December (19) }\end{array}$
\end{tabular}

\section{FACTORS RELATED TO THE SOWS}

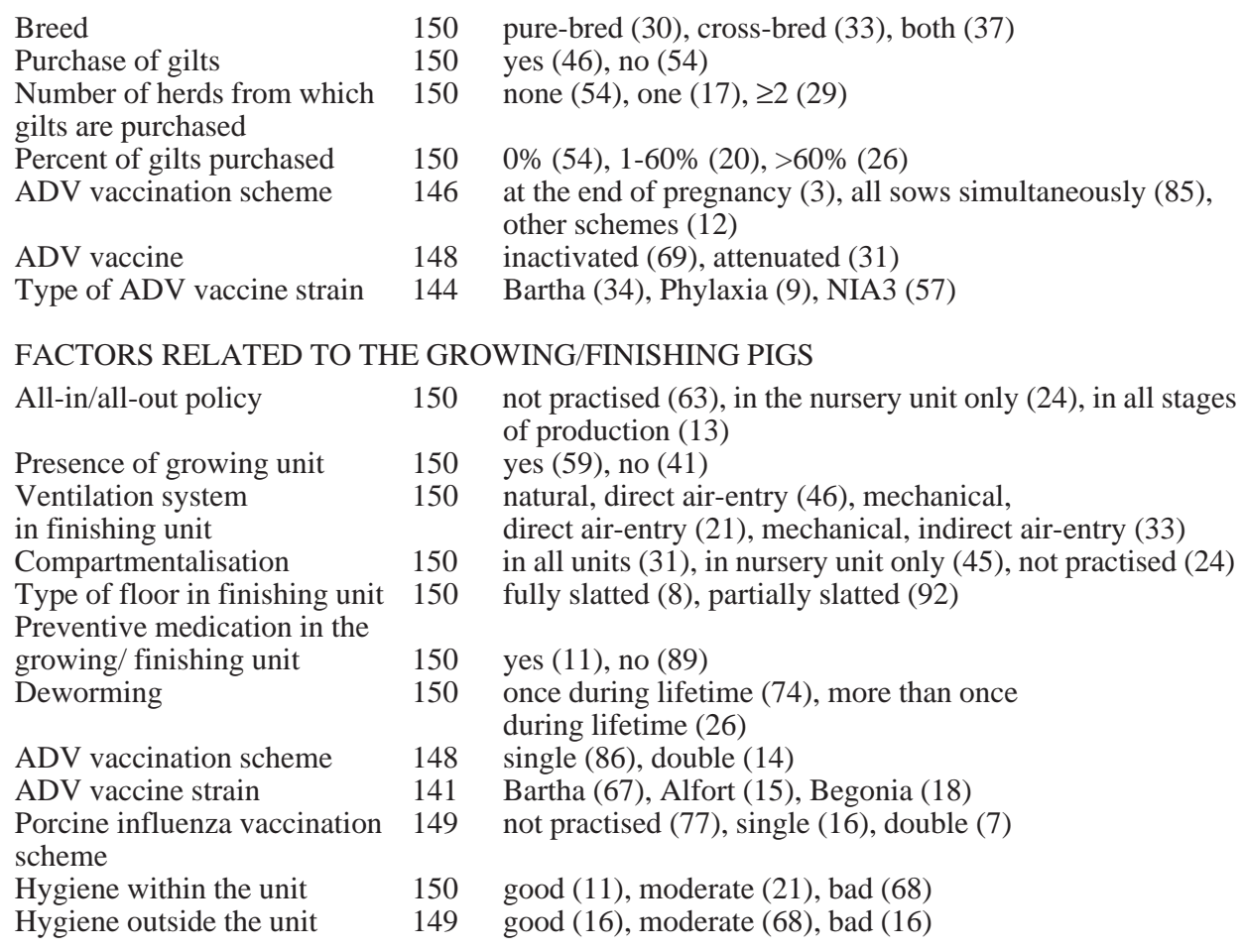

${ }^{a}$ Number of herds for which data were available.

or two times, and when a complete depopulation had taken place prior to restocking. Preventive medication of healthy pigs implied routine use of broad-spectrum antibiotics during 1 to 4 weeks in the feed or in the drinking water against respiratory or enteric diseases. Hygiene measures within the unit referred to cleansing followed by disinfection or a stand-empty period of minimum three days between two production groups. Hygiene measures outside the unit referred to biosecurity measures, that is prevention of disease entry by lorries carrying pigs, feed, or manure, presence of a sanitary room, use of unit boots, clothing, and protective head-gear. The hygiene within and outside the herds was considered to be good, moderate or bad when these hygiene measures were always, sometimes or never practised. 


\subsection{Slaughterhouse inspection}

The FP were slaughtered at the age of approximately 6 months when they reached $105-110 \mathrm{~kg}$ liveweight. Slaughter took place within three weeks after the lead author visited the herd. From the 60 to 150 pigs sent to the slaughterhouse, 25 pigs per herd were blood sampled. Samples were taken at fixed intervals, starting with the first pig. The interval was determined by dividing the total number of FP delivered by 25 . The systematic sampling scheme was not considered to have biased the serological data of the batch that was sent to slaughter. Although it cannot be ruled out that cluster effects may have occurred within a herd by investigating only one group of pigs per herd, we insisted that the herd owner send a representative group of pigs to slaughter, that is a group without many poor performers or good performers.

\subsection{Serological testing}

Antibodies were measured on $25(\mathrm{Mh}$, ADV) or 10 (both influenza viruses) blood samples per herd with commonly used serological tests. The 10 samples used to detect antibodies against both influenza viruses were randomly selected from the 25 blood samples.

The presence of antibodies against $\mathrm{Mh}$ was determined with the DAKO ${ }^{\circledR} \mathrm{Mh}$ ELISA (DAKO, Glostrup, Denmark) [14]. The DAKO ${ }^{\circledR}$ Mh ELISA detects antibodies to a Mh specific epitope localised on a $74-\mathrm{kDa}$ protein. Sera with OD-values $<50 \%$ and $\geq 65 \%$ of the $\mathrm{OD}_{\text {buffer control }}$ were considered positive or negative, respectively. Intermediate OD-values were considered doubtful and classified as negative in the statistical analyses. A standard haemagglutination-inhibition test (HI-test) was used to detect antibodies against influenza $\mathrm{H}_{1} \mathrm{~N}_{1}$ and $\mathrm{H}_{3} \mathrm{~N}_{2}$ viruses [33]. HI-titers were expressed as the inverse of the highest serum dilution that yielded complete inhibition of haemagglutination activity. HI-titers $\geq 4$ and $\geq 20$ were considered positive for influenza $\mathrm{H}_{1} \mathrm{~N}_{1}$ and $\mathrm{H}_{3} \mathrm{~N}_{2}$ viruses, respectively. Only sera of herds where FP were not vaccinated against influenza were analysed $(n=115)$. The presence of anti-gE-antibodies against ADV wild virus was determined with the Ingelvac ${ }^{\circledR}$ Aujeszky ELISA (Svanova Diagnostics, Uppsala, Sweden) [3]. This test allows differentiation of a vaccinated pig from an infected pig. Sera with OD-values $<45 \%$ and $\geq 55 \%$ of the $\mathrm{OD}_{\text {negative control }}$ were considered positive or negative, respectively. Intermediate OD-values were considered doubtful and classified as negative in the statistical analyses.

The 4 serological tests have a high specificity and sensitivity [3, 33, 35]. None of these tests discriminated between different isotype classes of immunoglobulins. Antibody titres raised against the four pathogens during the fattening period, that is in pigs from approximately 3 months until 6-7 months, were considered to being detectable until slaughter age.

\subsection{Statistical analyses}

The $95 \%$ confidence intervals of the within-herd seroprevalences were calculated as described by Wayne [45]. Associations between $\mathrm{Mh}$, influenza $\mathrm{H}_{1} \mathrm{~N}_{1}$ and $\mathrm{H}_{3} \mathrm{~N}_{2}$, and ADV seroprevalences were tested using logistic regression analysis (SAS 6.12, GLIMMIX, 1997) [37]. The herd was included as a random effect [24]. Associations between the seroprevalences of two different agents were expressed by the odds ratio (OR) and they were analysed in two directions, with either agent as the dependent and independent variable.

Logistic regression analysis (SAS 6.12, PROC GENMOD, 1997) [37] was also used to assess the associations, at the herd-level, between the proportion of seropositive pigs (dependent variable) and potential risk indicators (independent variables). Overdispersion due to the non-independence between 
pigs of the same herd [29] was taken into account by including a scale parameter in the logistic model [10]. A forward stepwise procedure was used to select the variables which were significantly $(P<0.05$; twosided) associated with the different seroprevalences [32]. At each step, the variable with the lowest $P$-value was added to the model. This procedure was continued until no additional variables were significant. If any design variable of a categorical variable was significant, then any other associated design variables were retained in the model. First-order interaction terms between significant independent variables were also tested in the intermediate and final models, and included if they were significant $(P<0.05$; two-sided). Squared terms of significant continuous variables were analysed in order to assess the assumption of linearity in the logit of the seroprevalence within the range of observed values [20]. In order to assess the goodness of fit of the final models [30], root mean squared errors (RMSE) were calculated according to the following

formula: $\sqrt{\frac{1}{n} \sum\left(\mathrm{P}_{\text {observed }}-\mathrm{P}_{\text {fitted }}\right)^{2}}$ with $\mathrm{n}$

denoting the number of herds, and $\mathrm{P}$ denoting the herd seroprevalence. Potential values for RMSE range between $0 \%$ and $100 \%$ with these endpoints corresponding to perfect predictability or complete lack of predictability by the model, respectively. ORs and $95 \%$ confidence intervals were calculated from the final logistic regression models.

\section{RESULTS}

The within-herd seroprevalences and 95\% confidence intervals are presented in Table IV. The median within-herd seroprevalences were $76 \%$ for $\mathrm{Mh}, 100 \%$ for $\mathrm{H}_{1} \mathrm{~N}_{1}, 40 \%$ for $\mathrm{H}_{3} \mathrm{~N}_{2}$, and $53 \%$ for ADV. The mean seroprevalences of $\mathrm{Mh}$ in the bimonthly periods were: J-F 68, M-A 82, M-J 75, J-A 68, S-O 72, N-D 68. The seasonal variation for both influenza viruses was not significantly different between the bi-monthly periods. The mean seroprevalences of $\mathrm{ADV}$ in the bi-monthly periods were: J-F 40, M-A 71, M-J 44, J-A 36, S-O 47, N-D 57. The minimum and maximum within-herd seroprevalences for each pathogen were $0 \%$ and $100 \%$, respectively. The distributions of within-herd seroprevalences of $\mathrm{Mh}, \mathrm{H}_{1} \mathrm{~N}_{1}$ and $\mathrm{H}_{3} \mathrm{~N}_{2}$, and ADV are shown in Figure 1. The percentages of herds in which no seropositive pigs could be detected were: $1 \%$ for $\mathrm{Mh}, 4 \%$ for $\mathrm{H}_{1} \mathrm{~N}_{1}$, $20 \%$ for $\mathrm{H}_{3} \mathrm{~N}_{2}$, and $24 \%$ for ADV. The percentages of herds in which all investigated pigs were seropositive for the different pathogens were: $\mathrm{Mh} 7 \%, \mathrm{H}_{1} \mathrm{~N}_{1} 77 \%, \mathrm{H}_{3} \mathrm{~N}_{2}$ $32 \%$, and ADV $31 \%$. The distribution of the within-herd seroprevalences of Mh was

Table IV. Within-herd seroprevalences of Mycoplasma hyopneumoniae (Mh), influenza $\mathrm{H}_{1} \mathrm{~N}_{1}$ and $\mathrm{H}_{3} \mathrm{~N}_{2}$ viruses, and Aujeszky disease virus (ADV) in slaughter pigs from 150 farrow-to-finish pig herds.

\begin{tabular}{lcccc}
\hline & \multicolumn{4}{c}{ Within-herd seroprevalences } \\
\cline { 2 - 5 } & $\mathrm{Mh}$ & $\mathrm{H}_{1} \mathrm{~N}_{1}$ & $\mathrm{H}_{3} \mathrm{~N}_{2}$ & ADV \\
\hline Minimum & $0[0-12]^{\mathrm{a}}$ & $0[0-27]$ & $0[0-27]$ & $0[0-12]$ \\
Median & $76[60-89]$ & $100[73-100]$ & $40[15-73]$ & $53[32-70]$ \\
Maximum & $100[88-100]$ & $100[73-100]$ & $100[73-100]$ & $100[88-100]$
\end{tabular}

${ }^{a}$ Between brackets: $95 \%$ confidence intervals. 

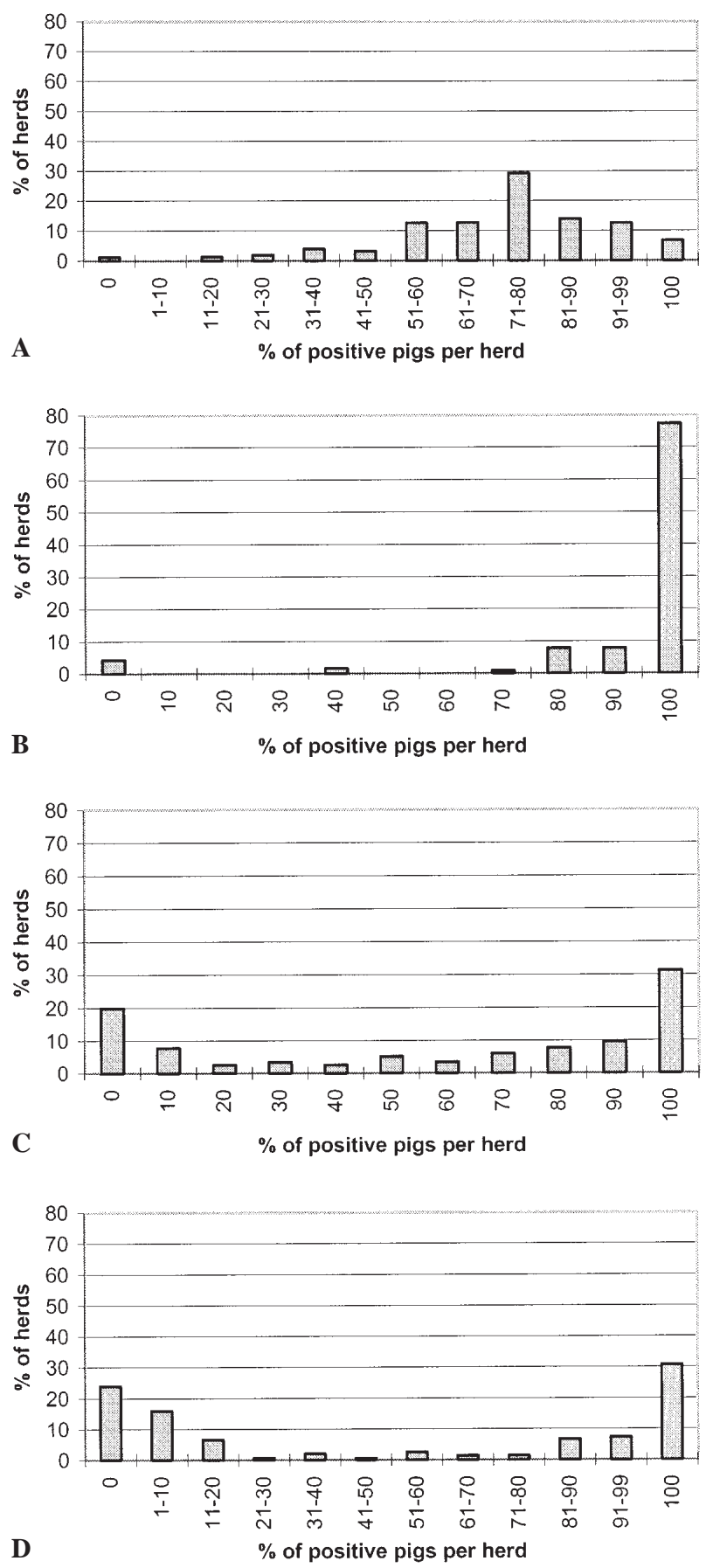

Figure 1. The distribution of the within-herd seroprevalence of Mycoplasma hyopneumoniae (A), influenza $\mathrm{H}_{1} \mathrm{~N}_{1}$ virus (B), influenza $\mathrm{H}_{3} \mathrm{~N}_{2}$ virus (C), and Aujeszky disease virus (D). 
skewed with a larger tail towards the lower seroprevalences, whereas the within-herd seroprevalences of the influenza $\mathrm{H}_{1} \mathrm{~N}_{1}$ virus showed less variation because almost all FP were seropositive. The distribution of the within-herd seroprevalences of ADV, and to a lesser extent of the influenza $\mathrm{H}_{3} \mathrm{~N}_{2}$ virus, showed a bimodal distribution with only $13 \%$ and $21 \%$ of the herds in the range of 20 to $80 \%$ seroprevalence, respectively.

Influenza $\mathrm{H}_{3} \mathrm{~N}_{2}$ virus seropositive pigs had a 2.29 times higher risk $(P<0.05)$ to be seropositive for the influenza $\mathrm{H}_{1} \mathrm{~N}_{1}$ virus than those that were $\mathrm{H}_{3} \mathrm{~N}_{2}$ seronegative. Conversely, influenza $\mathrm{H}_{1} \mathrm{~N}_{1}$ virus seropositive pigs had a 2.06 times higher risk (NS) to be seropositive for the $\mathrm{H}_{3} \mathrm{~N}_{2}$ virus. ADV seropositive pigs had a lower risk $(\mathrm{OR}=0.35 ; P<0.05)$ to be seropositive for the influenza $\mathrm{H}_{1} \mathrm{~N}_{1}$ virus and vice versa $(\mathrm{OR}=0.30 ; P<0.05)$. The other associations between seroprevalences were not significant.

The risk indicators associated with the proportion of pigs seropositive for $\mathrm{Mh}$, influenza $\mathrm{H}_{1} \mathrm{~N}_{1}$ and $\mathrm{H}_{3} \mathrm{~N}_{2}$ viruses, and ADV are listed in Table $\mathrm{V}$. The seroprevalence of Mh increased with the purchase of gilts, and with slaughter dates in March-April. The seroprevalence of the influenza $\mathrm{H}_{1} \mathrm{~N}_{1}$ virus was higher with higher densities of pig herds in the municipality. The percentage of pigs seropositive for the influenza $\mathrm{H}_{3} \mathrm{~N}_{2}$ virus was higher with increasing numbers of pig herds in the municipality and with increasing numbers of FP per pen. The proportion of ADV seropositive pigs increased with higher airspace stocking densities in the finishing units, higher herd sizes, more pig herds in the municipality, and with slaughter dates in March-April.

The interaction terms and the squared terms of the continuous independent variables in the intermediate and final models were not significant. RMSE values for the final models were $19 \%$ for $\mathrm{Mh}, 38 \%$ for the influenza $\mathrm{H}_{1} \mathrm{~N}_{1}$ and $\mathrm{H}_{3} \mathrm{~N}_{2}$ viruses, and $37 \%$ for ADV.

\section{DISCUSSION}

The herds involved in this study are representative of the population of FTF pig herds with over 50 sows because they were selected at random within the selected region, and because the percentage of nonresponders (13\%) was fairly low [43]. The different number of blood samples for the respective pathogens that is 25 for $\mathrm{Mh}$ and ADV and 10 for both influenza viruses, was partly determined by practical and budget considerations. These numbers permitted to detect at least one seropositive pig at the 95\% confidence level from a group of 150 pigs for minimum seroprevalences of $11 \%$ and $25 \%$, respectively. Martin et al. [28] and Carpenter and Gardner [7] have illustrated some features that should be considered in interpreting individual results of an imperfect test performed on a sample from a herd. The latter authors showed that increasing the number of pigs tested per herd, results in increases in herd sensitivity, especially for seroprevalences below $80 \%$. For seroprevalences more than $80 \%$, increasing the number of pigs tested per herd results in decreases in herd sensitivity, especially when the sensitivity of the test is $<90 \%$. Applied to the seroprevalences of both influenza viruses in our study, increasing the number of tested pigs per herd would have resulted in an increase in herd sensitivity for the influenza $\mathrm{H}_{3} \mathrm{~N}_{2}$ virus, but would have resulted in a slight decrease in herd sensitivity for the influenza $\mathrm{H}_{1} \mathrm{~N}_{1}$ virus.

The positive association between the seroprevalences of influenza $\mathrm{H}_{1} \mathrm{~N}_{1}$ and $\mathrm{H}_{3} \mathrm{~N}_{2}$ viruses corroborates with the results of Elbers et al. [11]. It is not possible to draw conclusions about whether the positive association between both influenza viruses results from similar management practices or environmental conditions promoting the spread of both pathogens, or whether infection with one virus predisposes to infection with the other virus. Evidence for the latter hypothesis, however, is not available. Moreover, from combined experimental infec- 
Table V. Risk indicators for the seroprevalences of Mycoplasma hyopneumoniae, influenza $\mathrm{H}_{1} \mathrm{~N}_{1}$ and $\mathrm{H}_{3} \mathrm{~N}_{2}$ viruses, and Aujeszky disease virus in slaughter pigs from 150 farrow-to-finish pig herds: parameters in the final logistic regression models, coefficients with standard errors, $P$-values and odds ratio with $95 \%$ confidence intervals (CI).

Final model for Mycoplasma hyopneumoniae (deviance 739; RMSE 19\%)

Parameters

intercept

purchase of gilts

slaughter date in March-April

scale parameter

$$
\begin{array}{ccc}
\text { Coefficients } \pm \text { standard error } & P \text {-value } & \text { Odds ratio }[95 \% \mathrm{CI}] \\
0.5830 \pm 0.1041 & <0.001 & \\
0.6656 \pm 0.1626 & <0.001 & 1.95[1.41-2.68] \\
0.6080 \pm 0.2442 & 0.013 & 1.84[1.14-2.96] \\
2.1375 \pm 0.0000 & - &
\end{array}
$$

Final model for the $\mathrm{H}_{1} \mathrm{~N}_{1}$ virus (deviance 419; RMSE 38\%)

Parameters

Coefficients \pm standard error $P$-value $\quad$ Odds ratio $[95 \% \mathrm{CI}]$

$\begin{array}{lccc}\text { intercept } & 0.9973 \pm 0.6105 & 0.102 & - \\ \text { number of pig herds in the municipality } & 0.6830 \pm 0.2975 & 0.022 & 1.98^{\mathrm{a}}[1.11-3.55] \\ \text { scale parameter } & 2.3161 \pm 0.0000 & - & -\end{array}$

scale parameter

$2.3161 \pm 0.0000$

Final model for the $\mathrm{H}_{3} \mathrm{~N}_{2}$ virus (deviance 879; RMSE 38\%)

Parameters

Coefficients \pm standard error

$P$-value

Odds ratio $[95 \% \mathrm{CI}]$

intercept

$-2.9361 \pm 1.1135$

0.008

number of pig herds in the municipality

number of fattening pigs per pen

$0.3800 \pm 0.1614$

$0.019 \quad 1.46^{\mathrm{a}}[1.07-2.01]$

scale parameter

$0.1844 \pm 0.0791$

$0.020 \quad 1.20^{\mathrm{b}}[1.03-1.40]$

Final model for Aujeszky disease virus (deviance 2914; RMSE 37\%)

Parameters

intercept

airspace stocking density in the

fattening unit

herd size

number of pig herds in the municipality

slaughter date in March-April

scale parameter
Coefficients \pm standard error

$0.5601 \pm 0.9542$

$-1.3050 \pm 0.3514$

$0.0064 \pm 0.0018$

$0.6029 \pm 0.1568$

$1.1970 \pm 0.4435$

$4.1865 \pm 0.0000$
$P$-value

Odds ratio $[95 \% \mathrm{CI}]$

a increase of one herd per $\mathrm{km}^{2}$.

$\mathrm{b}$ increase of one pig per pen.

c increase of $0.5 \mathrm{~m}^{3}$.

$\mathrm{d}^{\mathrm{increase}}$ of 50 sows tions with the porcine respiratory coronavirus (PRCV) and $\mathrm{H}_{1} \mathrm{~N}_{1}$ virus, it appeared that PRCV causes an interfering rather than a synergistic effect against the replication of $\mathrm{H}_{1} \mathrm{~N}_{1}$ [44]. The slightly different $P$-values and $\mathrm{ORs}$ between $\mathrm{H}_{1} \mathrm{~N}_{1}$ and $\mathrm{H}_{3} \mathrm{~N}_{2}$ (2.29 and 2.06) in the present study are caused by different variations in herd-seroprevalences with respect to both influenza viruses. In contrast to our results, Elbers et al. [11] 
found a slightly positive association $(\mathrm{OR}=1.2)$ between the seroprevalences of $\mathrm{H}_{1} \mathrm{~N}_{1}$ virus and ADV. The study population of Elbers et al. [11] consisted of pig-finishing herds whereas in the present study, only FTF pig herds were included. The significant negative association between the seroprevalences of both viruses observed in our study may also be explained by the fact that HI-antibodies were not examined in herds (23\%) where influenza vaccination was practised in the growing/finishing pigs. This procedure was preferred because the HI-test is not able to differentiate between infection and vaccination titres. Infections with ADV were more common in herds that vaccinated against influenza, there was a median within-herd seroprevalence of $74 \%$ versus $28 \%$ in herds that did not vaccinate against influenza, and it can be expected that infections with influenza viruses also occurred more frequently in these herds. By excluding these herds, a possible positive association between the seroprevalences of the $\mathrm{H}_{1} \mathrm{~N}_{1}$ virus and ADV may have been missed.

Jorsal and Thomsen [22] found that the risk for reinfection of SPF herds with Mh was significantly increased by the number of herds from which pigs are purchased and not by the frequency of purchase. Other investigators [1, 48] demonstrated a positive association between purchase of growing pigs and lung lesions. Since the present study was conducted in FTF pig herds, the effect of purchasing gilts and not of growing pigs was investigated. The variables used to measure the purchase of gilts were highly correlated (data not shown) and all of them were, individually taken, significantly associated with the seroprevalence of Mh. Purchase of gilts expressed as a yes/no variable was the most significant risk indicator. Various hypotheses can be raised to explain the positive association between purchase of gilts and the increased proportion of $\mathrm{Mh}$ seropositive slaughter pigs. Gilts often harbour Mh organisms in the respiratory tract. Transport and changes in management and housing conditions may decrease immunity in purchased gilts, and may lead to excretion of higher numbers of Mh when compared to gilts derived from own on-farm selection. Purchased gilts may also be responsible for the introduction of new, and possibly more pathogenic Mh strains [8] in the herd. Pigs slaughtered in March and April were at higher risk to be Mh seropositive compared to pigs slaughtered in other months. Although it cannot be ruled out that the worst herds were selected in March and April, the higher risk to be seropositive at slaughter in this period is probably due to the cold and wet weather during the winter [16]. Such conditions can promote the spread of Mh within and between herds. Furthermore, ventilation may be decreased during this period to maintain an optimal temperature in the units. Previous studies showed that the prevalence and severity of lung lesions [40], and the reinfection rate of SPF pig herds with Mh [38] were higher during the winter period.

Ewald et al. [13] found that a high regional pig density was a risk factor for herds to become infected with influenza $\mathrm{H}_{1} \mathrm{~N}_{1}$ and $\mathrm{H}_{3} \mathrm{~N}_{2}$ viruses. Similarly, we found that the proportion of seropositive pigs per herd increased with pig density in the municipality. A higher number of pigs or pig herds in the municipality may facilitate airborne transmission between herds, and may lead to increased contacts between herds [25]. An increase in the number of FP per pen was associated with a higher risk to be seropositive for the influenza $\mathrm{H}_{3} \mathrm{~N}_{2}$ virus. This factor allows more opportunities for direct nose-to-nose contact or for aerosol spread of the virus between penmates. Furthermore, a large number of pigs per pen creates physiological stress, which in turn can alter the immune system and predispose pigs to infection.

Decreased airspace stocking densities in the finishing unit were associated with a decreased risk to be $\mathrm{gE}$ positive for ADV. An increased air volume per pig results in a lower concentration of infectious particles, 
including ADV. This lower infection pressure leads to a decreased pig-to-pig transmission of ADV within the unit. Although the range in herd sizes (50-600 sows) was fairly small compared to other studies [18, 46], we did find a positive association between herd size and ADV seroprevalence. This is consistent with results obtained by Anderson et al. [2], Morrison et al. [31] and Christensen et al. [9], but it is in contrast with studies conducted by Weigel et al. [46]. ADV is introduced more often in large herds because they usually have more frequent contacts outside the herd than small herds. Furthermore, ADV may circulate persistently in a large herd because susceptible pigs are usually present, whereas the infection may fade out in small herds. Stegeman et al. [39] reported less ADV transmission in herds with 100 or more sows than in herds with less than 100 sows, but the authors ascribed the lower ADV seroprevalence in larger herds to confounding effects of better management procedures in these herds. The proportion of ADV seropositive pigs in the present study was higher in herds located in municipalities with a high pig herd density. This corroborates with results of previous studies [4, 27, 46]. Transmission experiments of ADV showed that a higher density of pigs increases ADV spread because of the higher number of contacts between the pigs [6]. In a pig-dense region, the contacts by area spread increase and as a result, ADV may circulate more easily. The type of transmission modes by which ADV was transferred between the herds, however, cannot be elucidated from the present study. Pigs slaughtered in March and April had the highest risk to be seropositive against ADV. The higher risk in March and April can be attributed to the same factors as those mentioned above for Mh. These factors promote survival of the virus within a herd and transmission of the virus between herds [5]. The prevalence of anti-gE antibodies was fairly high. This may be due to the fact that vaccination against ADV became mandatory in Belgium (Flanders) only in 1993, that is approximately two years before the present study.

Within each independent categorical variable, two or more biological relevant categories have been made (Tab. III). For a limited number of independent categorical variables namely $A D V$ vaccination scheme, type of floor in the finishing unit and porcine influenza vaccination scheme, the frequency rate was less than $10 \%$ in one of the categories. Although no trend could be observed between the different categories of these variables, this situation may have led to nonsignificant results.

The spread of the four pathogens was investigated by assessing the proportion of seropositive pigs in each herd. Serological testing has the characteristic that clinical as well as subclinical infections are detected. Consequently, the risk indicators found in this study are probably different from factors influencing the severity of clinical respiratory symptoms. Success at preventing disease occurrence may be greater by concentrating on occurrence and spread of infections, rather than focusing solely on clinical disease. Elbers et al. [11] demonstrated that infections with both influenza viruses and ADV are also economically important since pigs seropositive with respect to these agents showed a significant decrease in daily weight gain compared to seronegative pigs. In addition, Maes et al. [26] found that pig herds subclinically infected with EP achieved a significantly higher daily weight gain through vaccination against $\mathrm{Mh}$. The percentage of seropositive pigs within the herds may be influenced by the spread of infections within and between herds.

Finally, some comments should be made with regard to the use of a cross-sectional study design and the causality of the risk indicators. First, the study took one year but only one group of pigs from each herd was investigated in the slaughterhouse. Consequently, within each herd, it was only possible to trace infections during a fairly short 
period namely those that occurred approximately 4-5 months prior to slaughter. In addition, because cross-sectional studies measure events at a particular time, they suffer from the fact that cause and effect are sometimes difficult to separate. The risk indicators found in this study however, essentially fulfilled the criteria which are used to transpose observed associations into causal relations [41]. Second, unmeasured variables associated with the seroprevalences of the investigated pathogens may be potent sources of confounding [43]. In order to minimise a possible background noise mediated by such factors, a large number of variables known to be associated with respiratory disease were included in the analyses. The RMSE values of the final logistic models were fairly low (Tab. V). This corresponds to a fairly high to moderate predictability of the final models [30].

In conclusion, the present study pointed out for the first time that purchase of gilts, a high number of pigs per pen, and a high airspace stocking density in the fattening unit increased the risk for pigs to become seropositive for $\mathrm{Mh}, \mathrm{H}_{3} \mathrm{~N}_{2}$ and $\mathrm{ADV}$, respectively. The results confirmed that the winter period, a high regional density of pig herds, and a large herd size constitute important risk factors for the spread of respiratory pathogens. Purchase of gilts, a high number of pigs per pen, and a high airspace stocking density are risk indicators that can be managed directly by farmers striving to attain or to sustain a high health status of the pigs. Density of pig herds in the municipality and herd size are less manageable by the farmers; these factors should be considered by the government in search for optimal control measures against these pathogens.

\section{ACKNOWLEDGEMENTS}

This work was supported by grant 942063 from IWT Brussels and by Pfizer Animal Health. Prof. Dr. J.H.M. Verheijden (Faculty of Veterinary Medicine, University of Utrecht, The Netherlands) and Prof. Dr. H. Nauwynck (Faculty of
Veterinary Medicine, University of Ghent) are acknowledged for helpful comments. The authors thank the pig owners for collaboration, the personnel from the abattoirs for their assistance in blood sampling, and the laboratory workers for analysing the blood samples.

\section{REFERENCES}

[1] Aalund O., Willeberg P., Mandrup M., Riemann H., Lung lesions at slaughter: Associations to factors in the pig herd, Nord. Vet. Med. 28 (1976) 487-495.

[2] Anderson P., Morrison R., Molitor T., Thawley D., Factors associated with circulation of pseudorabies virus within swine herds, J. Am. Vet. Med. Assoc. 196 (1990) 877-880.

[3] Arias M., Moyano M., Escribano J., SánchezVizcaino J., Evaluation of two ELISA kits for the detection of Aujeszky's disease antibodies in pigs, Vet. Rec. 131 (1992) 391-393.

[4] Austin C., Weigel R., Factors affecting the geographic distribution of pseudorabies (Aujeszky's disease) virus infection among swine herds in Illinois, Prev. Vet. Med. 13 (1992) 239-250.

[5] Beran G., The epidemiology of pseudorabies, in: Proc. Pork Producers Day, Iowa State University, Ames, AS 535-G, 1982, pp. 1-9.

[6] Bouma A., de Jong M., Kimman T., Transmission of pseudorabies virus within pig populations is independent of the size of the population, Prev. Vet. Med. 23 (1995) 163-172.

[7] Carpenter T., Gardner I., Simulation modeling to determine herd-level predictive values and sensitivity based on individual-animal test sensitivity and specificity and sample size, Prev. Vet. Med. 27 (1996) 57-66.

[8] Chen J., Zhang L., Song J., Hwang F., Dong Q., Liu J., Comparative analysis of glycoprotein and glycolipid composition of virulent and avirulent strain membranes of Mycoplasma hyopneumoniae, Curr. Microbiol. 24 (1992) 189-192.

[9] Christensen L., Mousing J., Mortensen S., Sørensen K., Strandbygaard S., Henrikson C., Andersen J., Evidence of long distance airborne transmission of Aujeszky's disease (pseudorabies) virus, Vet. Rec. 127 (1990) 471-474.

[10] Collett D., Overdispersion, in: Modelling binary data, Chapter 6, Chapman and Hall (Eds.), London, UK, 1996, pp. 188-221.

[11] Elbers A., Tielen M., Cromwijk W., Hunneman W., Sero-epidemiological screening of pig sera collected at the slaughterhouse to detect herds infected with Aujeszky's disease virus, porcine influenza virus and Actinobacillus (Haemophilus) pleuropneumoniae in the framework of an Integrated Quality Control (IQC) system, Vet. Q. 12 (1990) 221-230. 
[12] Elbers A., Tielen M., Cromwijk W., Hunneman W., Variation in seropositivity for some respiratory disease agents in finishing pigs: epidemiological studies on some health parameters and farm management conditions in the herds, Vet. Q. 14 (1992) 8-13

13] Ewald C., Heer A., Havenith U., Factors associated with the occurrence of influenza $A$ virus infections in fattening swine, Berl. Münch. Tierärztl. Wochenschr. 107 (1994) 256-262.

[14] Feld N., Qvist P., Ahrens P., Friis N., Meyling A., A monoclonal blocking ELISA detecting serum antibodies to Mycoplasma hyopneumoniae, Vet. Microbiol. 30 (1992) 35-46.

[15] Gloster J., Donaldson A., Hough M., Analysis of a series of outbreaks of Aujeszky's disease in Yorkshire in 1981-82: The possibility of airborne disease spread, Vet. Rec. 114 (1984) 234-239.

[16] Goodwin R., Apparent reinfection of enzootic pneumonia-free herds: Search for possible causes, Vet. Rec. 116 (1985) 690-694.

[17] Haesebrouck F., Pensaert M., Prevalence of $\mathrm{H}_{1} \mathrm{~N}_{1}$ and $\mathrm{H}_{3} \mathrm{~N}_{2}$ influenza $\mathrm{A}$ viruses in fatteners in Belgium, Vl, Tijdschrd. Diergeneesk. 55 (1986) 1216.

[18] Hall W.F., Weigel R.M., Siegel A.M., Wiemers J.F, Lehman J.R., Taft A.C., Anneli J.F., Prevalence of pseudorabies virus infection and associated infections in six large swine herds in Illinois, J. Am. Vet. Med. Assoc. 198 (1991) 1927-1931.

[19] Horst I., Lindner A., Krüger M., Gindele H., Sting R., Verbreitung der Mycoplasma hyopneumoniae Infektion in Deutschland. Schlußfolgerungen für die Bekämpfung der Enzootischen Pneumonie der Schweine, Tierärztl. Umschau 52 (1997) 508514.

[20] Hosmer D., Lemeshow S. (Eds.), Applied logistic Regression, 1st ed., Wiley, New York, 1989, pp. 38-173.

[21] Hurnik D., Dohoo I., Bate L., Types of farm management as risk factors for swine respiratory disease, Prev. Vet. Med. 20 (1994) 147-157.

[22] Jorsal S., Thomsen B., A Cox regression analysis of risk factors related to Mycoplasma suipneumoniae reinfection in Danish SPF-herds, Acta Vet. Scand. [suppl] 84 (1988) 436-438.

[23] Leontides L., Ewald C., Willeberg P., Herd risk factors for serological evidence of Aujeszky's disease virus infection of breeding sows in Northern Germany (1990-1991), J. Vet. Med. B 41 (1994) 554-560

[24] Littell R., Milliken G., Stroup W., Wolfinger R., System for mixed models, SAS institute Inc., Cary, NC, USA, 1996, pp. 633.

[25] Madec F., Gourreau J., Kaizer C., Epidemiology of swine influenza $\mathrm{H}_{1} \mathrm{~N}_{1}$ on farms in Brittany (first outbreak-1982), Epidémiol. Santé Anim. 2 (1982) 56-64.

[26] Maes D., Deluyker H., Verdonck M., Castryck F., Miry C., Vrijens B., de Kruif A., Effect of vaccination against Mycoplasma hyopneumoniae in pig herds with an all-in/all-out production system, Vaccine 17 (1999) 1017-1023.

[27] Marsh W., Damrongwatanapokin T., Larntz K., Morrison R., The use of a geographic information system in an epidemiological study of pseudorabies (Aujeszky's disease) in Minnesota swine herds, Prev. Vet. Med. 11 (1991) 249-254

[28] Martin S., Shoukri M., Thorburn M., Evaluating the health status of herds based on tests applied to individuals, Prev. Vet. Med. 14 (1992) 33-43.

[29] McDermott J., Schukken Y., Shoukri M., Study design and analytic methods for data collected from clusters of animals, Prev. Vet. Med. 18 (1994) 175-191.

[30] Mittlböck M., Schemper M., Explained variation for logistic regression, Stat. Med. 15 (1996) 19871997.

[31] Morrison R., Marsh W., Anderson P., Thawley D., Factors associated with the seroprevalence of Pseudorabies virus in breeding swine from quarantined herds, J. Am. Vet. Med. Assoc. 199 (1991) 580-583.

[32] Neter J., Wasserman W., Kutner M., in: Applied Linear Statistical Models, Irwin (Chap. 12), 1990, pp. 433-483.

[33] Palmer D., Coleman M., Dowdle W., Schild G., Advanced laboratory techniques for influenza diagnosis, U.S. Department of Health, Education and Welfare. Immunology series $\mathrm{N}^{\circ} 6$, (1975) 2562

[34] Ross R., Mycoplasmal disease, in: Straw B.E. Mengeling W.L., D'Allaire S., Taylor D.J. (Eds.), Diseases of Swine, 8th ed., Iowa State University Press, Ames, IA, 1999, pp. 495-509.

[35] Sørensen V., Ahrens P., Barfod K., Feenstra A., Feld N., Friis N., Bille-Hansen V., Jensen N. Pedersen M., Mycoplasma hyopneumoniae infection in pigs: Duration of the disease and evaluation of four diagnostic assays, Vet. Microbiol. 54 (1997) 23-34.

[36] Sanitel, Ministry of Agriculture and Middle Classes, Veterinary Inspection, World Trade Centre III, Boulevard Simon 30, 1210 Brussels, 1994.

[37] SAS, Statistical Analysis Systems: Basics and Statistics Manual, SAS Institute Inc., Cary, NC, USA, 1997.

[38] Stärk K., Keller H., Eggenberger E., Risk factors for the reinfection of specific pathogen-free pig breeding herds with enzootic pneumonia, Vet. Rec. 131 (1992) 532-535.

[39] Stegeman A., Elbers A., van Oirschot J., Hunneman W., Kimman T., Tielen M., A retrospective study into characteristics associated with the seroprevalence of pseudorabies virus-infected breeding pigs in vaccinated herds in the southern Netherlands, Prev. Vet. Med. 22 (1995) 273283

[40] Straw B., Backström L., Leman A., Evaluation of swine at slaughter. I. The mechanics of exam- 
ination, and epidemiologic considerations, Compendium on continuing education for practising veterinarian 8 (1986) 541-548.

[41] Susser M., The logic of Sir Karl Popper and the practice of epidemiology, Am. J. Epidemiol. 124 (1986) 711-718.

[42] Thomsen B., Jorsal S., Andersen S., Willeberg $\mathrm{P}$., The Cox regression model applied to risk factor analysis of infections in the breeding and multiplying herds in the Danish SPF system, Prev. Vet. Med. 12 (1992) 287-297.

[43] Thrusfield M., Surveys, in: Veterinary Epidemiology, Second Edition, Chapter 13, Blackwell Science, 1997, pp. 178-197.

[44] Van Reeth K., Pensaert M., Porcine respiratory coronavirus-mediated interference against influenza virus replication in the respiratory tract of feeder pigs, Am. J. Vet. Res. 55 (1994) 12751281 .
[45] Wayne W., Confidence limits for a proportion, in: Applied nonparametric statistics, 2nd ed., 1990.

[46] Weigel R., Austin C., Siegel A., Biehl L., Taft A., Risk factors associated with the seroprevalence of pseudorabies virus in Illinois swine herds, Prev. Vet. Med. 12 (1992) 1-13.

[47] Wensworth D., Thompson B., Xu X., Regnery H., Cooley J., McGregor M., Cox N., Hinshaw V., An influenza $\mathrm{A}\left(\mathrm{H}_{1} \mathrm{~N}_{1}\right)$ virus, closely related to swine influenza virus, responsible for a fatal case of human influenza, J. Virol. 68 (1994) 20512058.

[48] Willeberg P., Gerbola M., Madsen A., Mandrup M., Nielsen E., Riemann H., Aalund O., A retrospective study of respiratory disease in a cohort of bacon pigs, I. Clinico-epidemiological analyses, Nord. Vet. Med. 30 (1978) 513-525. 